University of Nebraska - Lincoln

DigitalCommons@University of Nebraska - Lincoln

2009

\title{
Influence of Vitamin K-Rich Plant Foods on Anticoagulant Baiting Efficacy in Wild House Mice, Wild Norway Rats, and Wild Black Rats
}

G. W. Witmer

USDA-APHIS-Wildlife Services, gary.w.witmer@usda.gov

P. W. Burke

Follow this and additional works at: https://digitalcommons.unl.edu/icwdm_usdanwrc

Part of the Environmental Sciences Commons

Witmer, G. W. and Burke, P. W., "Influence of Vitamin K-Rich Plant Foods on Anticoagulant Baiting Efficacy in Wild House Mice, Wild Norway Rats, and Wild Black Rats" (2009). USDA National Wildlife Research Center - Staff Publications. 990.

https://digitalcommons.unl.edu/icwdm_usdanwrc/990

This Article is brought to you for free and open access by the U.S. Department of Agriculture: Animal and Plant Health Inspection Service at DigitalCommons@University of Nebraska - Lincoln. It has been accepted for inclusion in USDA National Wildlife Research Center - Staff Publications by an authorized administrator of DigitalCommons@University of Nebraska - Lincoln. 


\title{
Influence of vitamin $\mathrm{K}$-rich plant foods on anticoagulant baiting efficacy in wild House Mice, wild Norway Rats, and wild Black Rats
}

\author{
G. W. WITMER' and P. W. BURKE
}

\begin{abstract}
Rodents introduced to islands have caused the extinction of many species of animals. Anticoagulant rodenticides are relied on to eradicate rodents from these islands, but if the rodents are eating plant materials that contain high amounts of vitamin $\mathrm{K}$ (the antidote to anticoagulants) anticoagulant rodenticides may not be effeciive. In a laboratory trial, individually caged Norway Rats Rattus norvegicus, Black Rats R. rattus and House Mice Mus musculus were fed fresh plant material high in vitamin $\mathrm{K}$ (Collards $[0.62 \mathrm{mg}$ vitamin $\mathrm{K}$ per $100 \mathrm{~g}$ ] and Brussels Sprouts $[0.19 \mathrm{mg}$ vitamin $\mathrm{K}$ per $100 \mathrm{gl})$ for a period of 7 days. When presented later with anticoagulant rodenticides $(0.0025 \%$ brodifacoum pellets or $0.005 \%$ diphacinone pellets) along with the diet of plant material, $94 \%$ of the rodents died. We conclude from this study that the presence of green feed rich in vitamin $K$ does not reduce the effectiveness of anticoagulant rodenticides. However, we add a word of caution on one of the findings of our study. While we think the low efficacy $(75 \%)$ we found in the case of brodifacoum and Black Rats was probably an artifact of small sample size in that treatment group, the result warrants further investigation.
\end{abstract}

Key words: anticoagulants, efficacy, invasive, rodent, Mus, Rattus, rodenticide, Vitamin K

\section{INTRODUCTION}

Introduced, invasive rodents pose a serious threat to the native flora and fauna of islands worldwide (Towns et al. 2006). Rats and mice can be very prolific on islands where they have few, if any, predators, and their omnivorous foraging has lead to the endangerment or extinction of numerous island species (Moors and Atkinson 1984; Alcover et al. 1998). Mlost seabirds that nest on islands have not evolved to deal with predation and are very vulnerable to introduced rodents (Dowding and Murphy 2001). There has been a concerted worldwide effort to eradicate introduced rats (and to a lesser extent, introduced house mice) from islands with numerous successes (e.g., Veitch and Clout 2002; Towns and Broome 2003; Howald et al. 2007; Witmer at al. 2007). Research by the United States Department of Agriculture's National Wildlife Research Center (NWRC) has resulted in the recent registration of a $0.005 \%$ diphacinone bait pellet and a $0.0025 \%$ brodifacoum bait pellet to be used for aerial broadcast baiting of conservation areas to manage or eliminate introduced rats (Witmer and Eisemann 2007).

At the 2nd National Invasive Rodent. Summit (Witmer and Eisemann 2005), a question was raised in a discussion session of rodent eradication specialists: what effect would the consumption of plants rich in vitamin $\mathrm{K}$ by the introduced rodents on an island have on the efficacy of anticoagulant rodenticides? No one knew the answer and the group identified this as a research need. There are several chemical formulations of vitamin $\mathrm{K}$ and the vitamin is required in metabolic activity in the liver in which essential blood-clotting proteins are synthesized (Robbins 1993; Tasheva 1995). Vitamin $\mathrm{Kl}$ is phytomenadione and it is produced by green plants. Vitamin K2 compounds (1-13, depending on the number of isoprenoid residues) are menaquinones and they are produced by bacteria. Vitamin K3 is menadione; this form is produced commercially and is added to animal feeds. The vitamin $\mathrm{K}$ requirements of vertebrates are met by dietary intake and microbial synthesis in the digestive system, but also by "recycling" of vitamin $\mathrm{K}$ in the liver (Hadler and Buckle 1992; Robbins 1993). Vertebrates require a constant supply of vitamin $\mathrm{K}$ to remain healthy and, in fact, the more vitamin $\mathrm{K}$ ingested by vertebrates, the more that is excreted (Harrington et al. 2007).

The United States Department of Agriculture (USDA) provides a listing of the vitamin $K$ content of a large number of food types (www.nal.usda.gov/fnic/foodcomp/Data/SR21/ nutrlist/sr2 1w430.pdf). The list makes it clear that certain leafy green vegetables are particularly rich in vitamin K. One such green leafy plant that contains high levels of vitamin $\mathrm{I}$ is the common dandelion (Taraxacum. officinale). This plant species is native to Europe, but its invasive capabilities have allowed it to become cosmopolitan in distribution in the world (Gleason 1952). It is only one of thousands of invasive plant species have be come established and naturalized in Australia (Groves 2002), Hawaii (Staples and Cowie 2001), and New Zealand (Clout and Lowe 2000). Miost of the islands that rodents have successfully invaded have diverse green plants available 
year-jound as food. Invasive rodents are omivorous and opportunistic in their feeding habits (King 1990, Menkhors and Kunght 2001, Witurer et al. 2006), but where they have become established on temperate islands, they must feed primarily on plant materials in the fall and winter when animal foods are much less available (Immes 1990).

A review of the scientific literature provided very little insight into the question posed earlier. The only relevant published work we Jocated was not with commensal rodents, but rather with Indian Gerbils Tatera indica. With that species, Chaudhary and Tripathi (2004) reported that sinall amounts of vitamin Is (1 mg/kg for 5 or 15 days) did not reverse the effects of the anticoagulant difethialone, but that a higher dose $(2 \mathrm{mg} / \mathrm{kg}$ for 15 days) did reverse the anticoagulant effects. Most literature on vitamin $\mathrm{K}$ effects on rodents and anticoagulant control methods address the vitamin $\mathrm{K}$ requirement of anticoagulant-resistant rats. Resistance to anticoagulants is controlled by a single gene and has become relatively common around the world where these rodenticides have been used repeatedly for long periods of time (Partridge 1980a). Resistant rats have a 4-20 times higher requirement for vitamin $\mathrm{K}$ (Partridge 1980a; MacNicoll and Gill 1993; Markussen et al. 2003). Generally, they" cannot "recycle" enough vitamin $\mathrm{K}$ material and must get it through other sources such as diet and copraphagy (i.e., re-ingestion of faeces; Partridge 1980b; Hadler and Buckle 1992). Several researchers noted that some commercial livestock feedstuffs are supplemented with a form of vitamin $\mathrm{K}$ and that the availability of these foodstuffs to rats may lessen the effectiveness of rodenticide baits (Partridge 1980b; MacNicholl and Gill 1993). Commercial rat chow's such as Formulab 5008 and Formulab 5001 (PMI Nutrition International, Inc., Brentwood, Missouri) each have small amounts of vitamin $\mathrm{K}$ (menadione form) added as a nutritional supplement; $3.2 \mathrm{ppm}$ and $0.5 \mathrm{ppm}$, respectively.

In this study, we determined if a rodent diet containing green vegetables rich in vitamin $\mathrm{K}$ would reduce the efficacy of two commonly-used anticoagulant rodenticides, brodifacoum (a single-feeding, second-generation anticoagulant) and diphacinone (a multiple-feeding, firstgeneration anticoagulant). The green vegetables used in the study were Collards (0.62 $\mathrm{mg}$ vitamin $\mathrm{K}$ per $100 \mathrm{~g}$ food according to USDA) with rats and Brussels Sprouts $(0.19 \mathrm{mg}$ vitamin $\mathrm{K}$ per $100 \mathrm{~g}$ food) with mice, based on brief pretrial food preferences. Because of the very high vitamin $\bar{K}$ content of the green vegetables selected for the trial, we considered this trial a "worst case scenario." That is, if the rodenticides are still effecive while the rodents are feeding on these plants, they should be effective regardless of what green plants the rodents are feeding on in a natural or human-altered enviromment. We hypothesized that the rats receiving vitanin K-rich plant foods would not have the same high mortality rate after anticoagulant exposure as rats fed the anticoagulant bait, but withaut the vitamin $\mathrm{K}$ supplement.

\section{METHODS}

Wild-caught Norway Rats Rathus norvegicus and House Mice Mus musculins were obtained from the property of private landowners (with permission) ini the Fort Collins, Colorado, asea. Wild-caught Black Rats $R$. rattus were obtained from Wildlife Services operations personnel in the Phoenix, Arizona, area. Trials were conducted in an indoor animal research room (mice) or an outdoor rodent building (rats) at the NWRC, Fort Collins, Colorado. Conditions in the indoor room were maintained at $22.2^{\circ} \mathrm{C}$, a relative humidity of $15 \%$, and a $12 \mathrm{hr}$ on/12 hr off light cycle. Conditions in the outdoor building (cement pit with $\mathrm{l} \mathrm{m}$ of soil and a metal roof overhead) were ambient. In September, the ambient conditions in Fort Collins, Colorado, consist of maximum temperatures of $29.4^{\circ} \mathrm{C}$, minimum temperatures of $2.2^{\circ} \mathrm{C}$, a daily average temperature of $14.4^{\circ} \mathrm{C}$, relative humidity of $12-20 \%$, and 14 hr of light and $10 \mathrm{hr}$ of darkmess.

Rats and mice in this study were maintained in individual cages and fed rat chow and apple slices daily. All received water ad libitum. Each cage had a den box and bedding material. For each rodent species, there were three groups of 10 animals randomly assigned to each of the three treatments except for Black Rats for which only a total of 10 animals were available for the study. An effort was made to balance the number of males and females in each group, but that depended on the ratio of males and fenales available at the start of the study. The three treatments were 1) green vegetable phus brodifacoum rodenticide bait, 2) green vegetable plus diphacinone rodenticide bait, and 3) green vegetable plus rodent chow (cointrol). The green, vitamin $\mathrm{K}$-rich vegetables tested in a pre-trial preference session were Brussels Sprouts, Collards, and Kale. These had been identified as being very high in vitamin $\mathrm{K}$ by the USDA (www.nal.usda.gov/fnic/foodcomp/Data/SR21/ nutrlist/sr21w430.pdf). In the pre-trial feeding, three types of green vegetables rich in vitamin $\mathrm{K}$ were offered to rodents overnight and the amount consumed was monitored by weighing before and after the pre-trial.

A two-choice, 10-day exposure rodenticide trial was conducted. The weight, sex, cage 
number, and treatment group of each rodent was recorcled before the initiation of the study. Rodents were fed rat chow and the green vegetable for 7 days prior to rodenticide exposure. We decided that 7 days of feeding on the green leafy vegetables would be an adequate period for the rodents to establish a baseline level of vitamin $\mathrm{K}$ because vertebrates do not store vitamin $\mathrm{K}$, must continually replenish their vitamin $\mathrm{K}$ supply from dietary sources, and excrete any excess amounts ingested (Harrington et al. 2007). They continued to receive water ad libitum throughout the study. On day 8 , all food was removed from all cages. Groups I (0.0025\% brodifacoum pellets) and 2 $(0.005 \%$ diphacinone pellets) received a weighed amount of rodenticide along with the fresh green vegetable. For rats, this was $40 \mathrm{~g}$ of rodenticide; for mice, it was $15 \mathrm{~g}$. The rodenticide bait was replenished each day, as needed, so that it was always available to the rodents during the next 10 days. Fresh green vegetable was replenished each clay, as needed, so that it was also available to the rodents during the next 10 days. Group 3 rodents (control) continued to receive the green vegetable and measured amounts of rat chow, starting with $40 \mathrm{~g}$ for rats and $15 \mathrm{~g}$ for mice and replenished as needed. Additionally, all rodents in this study received a small amount of vitamin $\mathrm{K}$ precursor (menadione) in their laboratory rat chow (Lab Diet's Formulab Diet 5008). Spillage under rack cages was gathered each day and weighed. At the end of the 10-day two-choice trial with rodenticides, all food was removed and weighed. All rodents went back to the maintenance diet of rodent chow and were observed for a 10-day postexposure period.

All rodents were examined twice daily by the study director or his designee and the condition of the rodents and any mortalities were recorded. Dead rodents were placed in individual, labeled zip-lock bags and refitigerated for later necropsy. When necropsied, they were examined for signs of anticoagulant poisoning as described by Stone et al. (1999). All rodents were euthanized and incinerated at the end of the study.

The EPA requires a rodenticide efficacy (i.e., mortality rate) of $90 \%$ in individually-caged rodent trials before it will consider issuing a registration for commercial use of the material as a legal rodenticicle in the United States (Schneider 1982). We compared our observed mortality rates with the EPA standard of $90 \%$ (as the expected mortality rate), using Chi Square contingency tests (SAS Institute 2003). We also used a two-way ANOVA test (SAS Institute 2003) to compare days to death by rodent species (Norway rat, black rat, house mouse) and by rodenticide type (diphacinone, broclifacoum). We used a probability level of $\mathrm{P}<0.05$ to determine significance of the statistical test result.

\section{RESULTS AND DISCUSSION}

The green vegetables fed to rats in the study were Collards $(0.62 \mathrm{mg}$ vitamin $\mathrm{K}$ per $100 \mathrm{~g}$ food according to USDA) and those fed to mice were Brussels Sprouts $(0.19 \mathrm{mg}$ vitamin $\mathrm{K}$ per $100 \mathrm{~g}$ food), based on the food preference pretrial. For perspective, the highest amount of vitamin $\mathrm{K}$ listed by the USDA in a fruit (plums) was $0.03 \mathrm{mg}$ per $100 \mathrm{~g}$ and in a meat (duck) was $0.004 \mathrm{mg}$ per $100 \mathrm{~g}$. After adjusting for vegetable weight loss due to evaporation, House Mice ate an average of $0.89 \mathrm{~g}(\mathrm{SD}=0.89)$ of Brussels Sprouts per day, Norway Rats ate an average of $13.3 \mathrm{~g}(\mathrm{SD}=4.0)$ of Collards per day, and Black Rats ate an average of $12.3 \mathrm{~g}$ (SD $=1.2$ ) of Collards per day. While the control animals gained weight over the course of the trial, the animals on rodenticide baits generally lost weight (Table 1). This occurs because rodents feeding on anticoagulant rodenticides continue feeding for a number of days, but eventually at a reduced rate as they near death from internal hemorrhaging.

Table 1. Weight change, mortality rate and time to death in rats and mice fed different rodenticide treatments, along with fresh plant material.

\begin{tabular}{|c|c|c|c|c|c|c|c|c|}
\hline \multirow[b]{2}{*}{ Treatment } & \multirow[b]{2}{*}{$N$} & \multicolumn{2}{|c|}{$\begin{array}{l}\text { Start } \\
\text { weight (g) }\end{array}$} & \multicolumn{2}{|c|}{$\begin{array}{l}\text { Weight } \\
\text { change (g) }\end{array}$} & \multirow[t]{2}{*}{$\begin{array}{l}\text { Mortality } \\
\text { rate }(\%)\end{array}$} & \multicolumn{2}{|c|}{$\begin{array}{c}\text { Time to } \\
\text { death (days) }\end{array}$} \\
\hline & & Mean & $\mathrm{SD}$ & Mean & $\mathrm{SD}$ & & Mean & SD \\
\hline \multicolumn{9}{|l|}{ Norway Rats } \\
\hline Brodifacoum & 10 & 907.38 & 49.89 & -10.44 & 19.45 & 100 & 6.40 & 2.50 \\
\hline Diplacinone & 10 & 236.66 & 54.30 & -9.01 & 14.00 & 1.00 & 0.30 & 1.19 \\
\hline Control & 10 & 234.69 & 78.57 & 17.39 & 10.36 & 0 & N/A & $N / A$ \\
\hline \multicolumn{9}{|l|}{ Black Rats } \\
\hline Brodifacoum & 4 & 175.75 & 6.56 & -24.35 & 9.23 & 75 & 10.00 & 2.45 \\
\hline Dipliaciuone & 4 & 184.63 & 38.70 & -14.13 & 5.14 & 100 & 8.75 & 2.86 \\
\hline Concrol & 2 & 160.55 & 1.15 & 1.90 & 7.10 & 0 & N/A & $N / A$ \\
\hline \multicolumn{9}{|l|}{ House Mice } \\
\hline Brodifacoum & 10 & 19.35 & 4.35 & -2.36 & 2.25 & 100 & 10.20 & 3.99 \\
\hline Diplacinone & 10 & 18.50 & 5.60 & 0.61 & 4.76 & 90 & 7.78 & 2.05 \\
\hline Colltrol & 10 & 15.90 & 4.68 & 2.74 & 3.76 & 0 . & $N / A$ & $N / A$ \\
\hline
\end{tabular}


Efficacy was high (94\% overall) for both brodifacoum and clipliacinone across all thee species of commensal rodents (Table 1). It was $90-100 \%$ effective in all cases excejt with brodifacoum and Black Rats (75\% efficacy). In all cases, the efficacy levels were not significantly different $(P>0.12)$ than the $90 \%$ required by the IPA. The lowest observed efficacy rate $(P=$ $0.12)$ was will brodifacoum and Black Rats. In this case, the efficacy of rate of only $75 \%$ may have been an artifacl of the small number of black rats (4) in that treatment group. Pitt ef al. (2008) used 10 Black Rats per treatment group in their rodenticide efficacy trials and achieved an efficacy rate of $90 \%$ for black rats with the same commercial brodifacoum pellets that we used in our study. We do not believe that genetic resistance to anticoagulants was a factor with our Black Rats because we had a high efficacy rate (100\%) with diphacinone, the other anticoagulant used in the trials. None of the control rodents died during the course of the study.

Rats ate $9.5-13.2 \mathrm{~g}$ of the rodenticide baits per day, while mice ate $2.5-2.8 \mathrm{~g}$ of the baits per day. The average time to death was $6.3-10.2$ days and always longer for rodents feeding on brodifacoum bait (Table 1). The statistical analysis of the time to death revealed a significant difference between species with Norway Rats having a shorter time to death than Black Rats or House Mice $(P=0.003)$. There was no significant difference between rodenticides and time of death $(P=0.109)$ and the interaction between species and rodenticide was also not significant $(P=0.371)$. The results of our study suggest that Norway Rats are more susceptible to anticoagulant rodenticides than are Black Rats or House Mice. In previous studies of the efficacy of a broad array of commercial rodenticides, we found that many more were effective with Norway Rats than with House Mice (Witmer 2007a, b). Fisher (2005) also reported a lower susceptibility of House Mice to anticoagulants than rats in New Zealand.

Most (90\%) of the dead treatment rodents showed signs of internal haemorrhaging upon necropsy, although a much smaller portion (40\%) showed extemal signs. Extemal signs were generally slight bleeding from the nose. The amount of vitamin $\mathrm{K}$ in these vitamin $\mathrm{K}$-rich green plants was not sufficient to overcome the lethal effects of the two anticoagulant rodenticides used in this study.

All rodents in this study received a small amount of vitamin $\mathrm{K}$ precursor (menadione) in their laboratory rat chow (Lab Diet's Formulab Diet 5008). The menadione content of this rodent chow is $3.2 \mathrm{ppm}(0.0032 \%)$. In previous rodenticide trials with wild Norway Rats and wild I-Iouse Mice, we found several anticoagulant rodenticides to be very efficacious even when the same rodent chow was used as the alternative food in the two-choice trials (Witner 2007a, b). We mention this point because some researchers bave suggested that that the availability of vitanin $\mathrm{K}$ supplements in aninual feedstuffs may lower anticoagulant rodenticide efficacy at livestock facilities infested witli anticoagulantresistant rats and mice (MacNicoll and Gil] 1993). Of course, with invalsive rodent eradication efforts on remote islands, supplemental animal feed would not be an issue. In some cases, however, those remote islands might contain vitamin $\mathrm{K}$-rich plants. The finding of this study suggest that managers do not need to worry about decreased efficacy of anticoagulant rodenticides from...vitamin K-rich plant consumption when those rodenticides are used to control or eradicate introduced rodents on islands. However, we add a word of caution on one of the findings of our study. While we think the low efficacy (75\%) we found in the case of brodifacoum and Black Rats was probably an artifact of small sample size in that treatment group, the result warrants further investigation.

\section{REFERENGES}

Alcover; J., Sans, A and Pahmer, M., 1998. The extent of exrinctions of mammals on isiands. $J$. Biogeogr: 25: $913-918$.

Chaudhary, V. and Tripathi, R., 2004. Effect of supplementary feeding of vitamin Is on difethialone treated Indian gerbils in the laboratory. Indian J. Exp. Bio. 42: 297-302.

Clout, M. and Lowe, S., 2000. Invasive species and emvironmental changes in New Zealand. Pp. 369-383 in Invasive Species in a Changing World ed by $H$. Mooney and R. Hobbs. Island Press, Washingron, D.C.

Dowcling, J: and Murphy, E., 2001. The impact of introduced mammals on enclemic shorebirds in New Zealand: a conservation perspective. Biol. Conzery 99: $47-64$.

Fisher, P., 2005. Review of house mouse susceptibility to anticoagulant rodenticides. DOC Science Internal Series 198. New Zealand Department of Conservacion, Wellington.

Gleason. H., 1952. Illustrated Flora of the Northeastern Unites States and Adjacent Canada. Lancaster Press, Laucaster; Peunsyjunia.

Groves, R., 2002. The impacts of alien plants in Australia. Pp. 1 1-23 in Biological Invasions ed by D. Pimentel. CRC, Press, Boca Raton, Florida.

Hadler; $M$. and Buckle, A., 1992. Forty-fjve years of anticoagulant rodenticides - past, present, and future trends. Tp. 149-155 in 15 th Vertebrate Pest Conference Proceedings ed by J. Borrecco and R. Marsh. California Vertebrate Council, Hyat Newporter, Newport Beach, California.

Harrington. D., Booth, S. Card. D. and Shearer; M., 2007. Excretion of Titamin $\mathrm{F}$ by young adults responds to changes in dietany phylloquinone and dihydrophylloquinone intakes. $j$. Nutv: 137: 1763-1768. 
Howalc, G., Donlan, C., Galvan, J., Russell. J., Parkes, J., Samaniego, A., Wand, Y., Veirch, D., Genovesi, P., Pascal, M., Saunclers, A. and Tershy, B., 2007. Invasive rodent eraclication on islands. Conserv. Biol. 21: 12581268.

Innes, J., 1990. Ship rat. Pp. 206-2925 in The Handbook of New Zealand Mammals ed by C. King. Oxford University' Press, Oxford.

King, C., ed, 1990. The Handbook of New Zealand Mammals. Oxford Universiry Press, Oxford.

MacNicoll, A. and Gill, J., 1993. Vitanin K in feedstuffs: antidotal effects in captive anticoagulant-resistant rats and mice. J. Fildll. Manage. 57: 835-841.

Markussen, M., Heiberg, A., Nielsen, R. and Leirs, H., 2003. Vitamin K requirement of Danish anticoagulantresiscant Norway rats. Pest Manage. Sci. 59: 913-990.

Menkhorst, P. and Knight, F, 2001. A Field Guide to the Mammals of Australia. Oxford University Press, Oxford.

Moors, P. J. and Atkinson, I. A. E., 1984. Predation on seabirds by introduced animals, and factors affecting its severity. ICBP Technical Publication 2: 667-690.

Partridge, G., 1980a. The vitamin I requirements of wild brown rats resistant to warfarin. Compar: Biochem. Physiol. 66A: 83-87.

Partridge, G, 1980b. Vitamin K deficiency syndromes in warfarin-resistant brown rats. Lab. Ainimals 14: 193-195.

Pitt, W. Updike, L., Sugihara, R. and Dorant, R., 2008. Efficacy of rodenticicle baits for the control of black rars, Polynesian rats, and mice. Final Report, QA-1344. USDA/APHIS/WS National Wildlife Research Center, Hilo Hawaii.

Robbins, C., 1993. Wildlife Nutrition and Feeding. Ind Ed. Academic Press, New York.

SAS Instituce, 2003. SAS Version. 9.1. SAS Institute, Cary, North Carolina.

Schneider, B., 1982. Pesticide Assessment Guidelines. EPA 540/9-82-026. U.S. Environmental Protection Agency, Washington, D.C.

Staples, G. and Cowie, R., 2001. Hawaii's invasive species. Hawaii Biological: Survey Handbook. Mutual Publishing, Honolulu, Hawaii.

Stone, W., Okoniewski, J. and Stedelin, J., 1999. Poisoning of wildlife with anticoagulant rodenticides in New York. J. Willdl. Dis. 35: 187-193.

Tasheva, M., 1995. Anticoagulant roclenticides. Environmental Health Criteria 175 . World Healch Organization, Geneva, Switzerdand.

Towns, D., Atkinson, I. and Daugherty, C., 2006. Have the harmful effects of introcinced rats on islands been exaggerated? Biol. Invas. 8: 863-891.

Towns, D. and Broome, K.. 2003. From small Maria to nassive Campbell: forty years of rat eradications from New Zealand islands. New Zealand J. Zool. 30: 377-398.

Veitch, C. R., and Clout, M. N., eds. 2002. Tuming the tide: the eradication of invasive species. IUCN SSC Invasive Species Specialist Group. IUCN, Gland, Switzerland and Cambridge. UIS.

Wimer, G., 2007a. Efficacy of commercially-available rodenticide baits for the control of introduced Norway rats. Final Report, QA-1232. USDA/APHIS/WS National Wildlife Research Center, Fort Collins, Colorado.
Witmer, G. 2007b. Efficacy of commercially available rodenticide baits for the control of wild house mice. Final Report, QA-1304. USDA/APHIS/WS National Wilcllife Research Center, Fort Collins, Colorado.

Witmer, G., Boyd, F, and Hillis-Starr; Z., 2007. The successful eradication of introduced rats from Buck Island using diphacinone, followed by an irruption of house nice. Wildl. Res. 34: 108-115.

Witmer, G., Burke, P., Jojola, S. and Dunlevy, P., 2006. The biology of introduced Norway rats on Kiska Island, Alaska, and an evaluacion of an eradication approach. Northtuest Sci. 80: 191-198.

Witmer, G. and Eisenann, J., 2005. An overview of the 2nd National Invasive Rodent Sunmit. $\mathrm{Pp} .102-111$ in 11 th Wildlife Damage Management Conference Proceedings ed by D. Nolte and K. Fagerstone. The Wildlife Management Damage Working Group of The Wildlife Society, The Hagerty Center, Traverse City, Michigan.

Witmer, G. and Eisemann, J., 2007. The use of rodenticides for conservation purposes. Pp. 160-167 in 12th Wildlife Damage Management Conference Proceedings ed by D. Nolte, W. Arjo and K. Fagerstone. The Wildlife Management Damage Working Group of the Wildilife Sociery, Bayfront Marina and Hotel, Corpus Christi, Texas. 